\title{
Review: kisspeptin and reproduction in the pig
}

\author{
C. A. Lents ${ }^{\dagger}$ \\ Reproduction Research Unit, U.S. Meat Animal Research Center, Agricultural Research Service, U.S. Department of Agriculture, PO Box 166, Clay Center, NE, 68933, USA
}

(Received 8 April 2019; Accepted 13 June 2019; First published online 18 July 2019)

The activation of the hypothalamic-pituitary axis is critical for the initiation and maintenance of reproductive cycles in pigs and is influenced by a number of factors, such as nutrition, metabolism and gonadal steroids. Kisspeptin is a neuropeptide that is expressed in discrete regions of the porcine hypothalamus and is positioned to mediate the action of many of these factors. The expression of kisspeptin in the pig hypothalamus does not appear to be regulated by gonadal steroids in the same way as other species. It is unclear if kisspeptin is mediating nutritional or metabolic effects on gonadotropin secretion in pigs as it takes large deficits in feed intake or BW to affect hypothalamic expression of the KISS1 gene in the porcine hypothalamus. There appears to be little genetic diversity in kisspeptin or its receptor that is useful for improving reproduction in swine. Both peripheral and central injection of kisspeptin strongly stimulates the secretion of gonadotropin hormones, LH and FSH, in gilts. Similarly, synthetic analogues have been developed and showed potential promise as tools to manage reproductive cycles in gilts and sows. Review of the literature nonetheless reveals that research on kisspeptin and its function in controlling reproduction in pigs has lagged that of other livestock species.

Keywords: swine, gonadotropin, cyclicity, puberty, nutrition

\section{Implications}

Kisspeptin has emerged as a key regulator of reproductive function in pigs. It acts within the central nervous system to stimulate the secretion of reproductive hormones from the anterior pituitary gland that promote the initiation and maintenance of reproductive cycles. Kisspeptin holds tremendous promise to provide new methods to control reproduction and fertility in pork production; however, research in swine has fallen behind that of other livestock species. Given the unique differences in the regulation of reproduction between livestock species, pig-specific research is needed to fully capture the benefits that kisspeptin can bring to improving reproduction in pigs.

\section{Introduction}

Reproductive failure is the number one reason for culling gilts and sows (Knauer et al., 2006; Tummaruk et al., 2009). Approximately $30 \%$ of replacement gilts never farrow (Stancic et al., 2011). A common reason for this is that gilts fail to become cyclic or their cyclicity is delayed beyond acceptable ages (Saito et al., 2011). Initiation of puberty is

\footnotetext{
† E-mail: clay.lents@ars.usda.gov
}

dependent upon the activation of the hypothalamicpituitary-gonadal axis. In general, pubertal development culminates with the activation of high-frequency pulses of LH (Diekman et al., 1983; Lutz et al., 1984; Camous et al., 1985) that are driven by cyclic increases in the secretion of gonadotropin-releasing hormone $(\mathrm{GnRH})$ from the hypothalamus (Lutz et al., 1985; Kraeling and Barb, 1990). Inadequate gonadotropin secretion also results in pubertal failure and contributes to prolonged wean to oestrus intervals in postpartum sows (Edwards and Foxcroft, 1983). Moreover, insufficient gonadotropin secretion can underlie seasonal dips in cyclicity of gilts and sows (Armstrong et al., 1986, Barb et al., 1991). Even though it has been known for many decades that dysregulation of the hypothalamic-pituitary axis contributes to reproductive inefficiency of pigs that results in considerable financial loss, little progress has been made in understanding the regulation of this key physiological process. In the last decade and a half, kisspeptin has emerged as being critically important in controlling gonadotropin secretion and is central to the effects of nutrition, disease, stress and season on gonadotropin secretion in laboratory and livestock species. The intent of this review is to examine the current state of knowledge regarding kisspeptin and regulation of reproduction in the pig with reference to other species where information in the pig may be lacking. 


\section{Kisspeptin and reproduction}

\section{Kisspeptin and central regulation of the reproductive neurosecretory axis}

Kisspeptin is the peptide product of the KISS1 gene (Kotani et al., 2001; Ohtaki et al., 2001). Synthesized as a preprohormone, kisspeptin is proteolytically cleaved to produce a series of peptides ranging from 10 to 54 amino acids in length. These kisspeptins share complete homology at the c-terminus and retain full biological activity. The kisspeptin receptor is a G-protein-coupled receptor that was found to be critical for the initiation of puberty in lab animals (Seminara et al., 2003). Kisspeptin and kisspeptin receptor gene expression are hormonally regulated (Navarro et al., 2004), and early studies revealed that central (intracerebroventricular, ICV) and peripheral (intravenous, IV; subcutaneous, SC) treatment with kisspeptin had potent stimulatory effects on the secretion of gonadotropin hormones in laboratory rodents (Matsui et al., 2004; Thompson et al., 2004) and nonhuman primates (Shahab et al., 2005). It was subsequently reported that kisspeptin powerfully stimulates gonadotropin secretion, particularly LH secretion, in livestock species, including sheep (Caraty et al., 2007a), goats (Hashizume et al., 2010), cattle (Kadokawa et al., 2008) and horses (Magee et al., 2009). Prepubertal gilts received one of two doses of kisspeptin $(10$ or $100 \mu \mathrm{g})$ injected in to the lateral ventricles of the brain (Lents et al., 2008). Both kisspeptin treatments produced a robust and immediate surge-like secretion of $L H$ that was sustained for several hours. The $10-\mu \mathrm{g}$ dose of kisspeptin elevated LH secretion for about $2 \mathrm{~h}$, whereas the 100$\mu \mathrm{g}$ dose increased $\mathrm{LH}$ for the entire 3 -h post-injection sampling period. The magnitude of this $\mathrm{LH}$ release was one-half to twothirds that induced by an IV injection of GnRH $(100 \mu \mathrm{g})$. The $100-\mu \mathrm{g}$ dose of kisspeptin also stimulated FSH secretion for over $3 \mathrm{~h}$, and this release of FSH was similar in magnitude to that stimulated by GnRH. These results firmly established that kisspeptin is a potent stimulant of LH in the pig. The more potent effect of kisspeptin in stimulating secretion of $\mathrm{LH}$ compared with FSH was attributed to the fact that $\mathrm{LH}$ secretion is more responsive to GnRH than is FSH. It was concluded that kisspeptin plays a major role in the onset of $L H$ pulses in the pig during puberty.

A substantial body of evidence indicates that the effect of kisspeptin to stimulate LH secretion occurs centrally within the hypothalamus. Kisspeptin receptor is expressed in GnRH neurons of the ovine hypothalamus (Smith et al., 2011), and kisspeptin-stimulated secretion of LH in ewes is accompanied by a concomitant release of GnRH (Messager et al., 2005; Caraty et al., 2007b). Moreover, kisspeptin failed to stimulate $\mathrm{LH}$ secretion in ewes treated with neutralizing antibodies to GnRH (Arreguin-Arevalo et al., 2007), and in ewes in which the hypothalamus had been disconnected from the pituitary to eliminate GnRH input to gonadotroph cells (Smith et al., 2008b), demonstrating that kisspeptin stimulates $\mathrm{LH}$ secretion in a GnRH-dependent manner. Although similar studies have not been reported for pigs, the spatial distribution of kisspeptin expression within the porcine hypothalamus implies kisspeptin regulation of $\mathrm{GnRH}$ neurons in the pig as well.

\section{Structural organization of kisspeptin neurons in the hypothalamus}

In the central nervous system of rodents, kisspeptin cells are localized primarily in two discrete regions involved in the regulation of gonadotropin secretion, including the anteroventral periventricular nucleus (AVPV) near the preoptic area (POA) and the arcuate nucleus (ARC; Smith et al., 2005). Livestock do not have a true AVPV similar to that in rodents; rather kisspeptin neurons are organized in the POA and ARC (Franceschini et al., 2006). Immunoreactive kisspeptin was localized in these regions to cell bodies and fibres. In the POA of the ewe, kisspeptin immunostaining was observed to extend from the organum vasculosum of the lamina terminalis to the opening of the preoptic recess into the third ventricle. During sexual maturation in the ewe, messenger RNA (mRNA) for kisspeptin is expressed in the discrete region of the periventricular (PeV) nucleus (Redmond et al., 2011a). Similarly, kisspeptin gene expression is found in the PeV of sexually mature and developing gilts (Tomikawa et al., 2010; leda et al., 2014). This is a similar area as the AVPV in mice and may be important for GnRH secretion controlling ovulation in pigs.

Kisspeptin mRNA is expressed in the medial basal hypothalamus (MBH) of gilts (Thorson et al., 2017) within the ARC (Tomikawa et al., 2010). A spatially distinct pattern of kisspeptin expression is seen throughout the ARC of the pig, with the greatest gene expression in the medio-caudal sections (Tomikawa et al., 2010; Thorson et al., 2018). This is similar to the ARC distribution of kisspeptin observed in sheep and cattle (Redmond et al., 2011a; Cardoso et al., 2015). The work on localization of kisspeptin within the porcine hypothalamus has thus far been limited to the expression of mRNA for the kisspeptin gene. Reports identifying the spatial distribution of kisspeptin-expressing cells with immunocytochemistry are lacking for pigs. Preliminary data demonstrate that neuronal cell body as well as nerve fibres can be identified within the porcine ARC (Figure 1). It is thus anticipated that the structural organization of kisspeptin neurons within the porcine ARC is similar to other species. Specifically, kisspeptin neurons in the POA act on GnRH cell bodies, whereas kisspeptin neurons in the ARC regulate $\mathrm{GnRH}$ terminal axons in the median eminence.

\section{Oestrogen feedback and expression of kisspeptin}

Escape from oestrogen negative feedback with advancing age is critical for increased LH secretion in gilts (Berardinelli et al., 1984; Barb et al., 2000; Barb et al., 2010a), but the mechanisms behind this hormonal regulation of reproduction are not understood. Oestrogen receptor is not expressed in GnRH neurons, suggesting that the feedback effects of oestrogen on the GnRH pulse generator are mediated through other afferent neurons. Kisspeptin neurons in sheep express oestrogen receptor alpha (Franceschini 
Lents

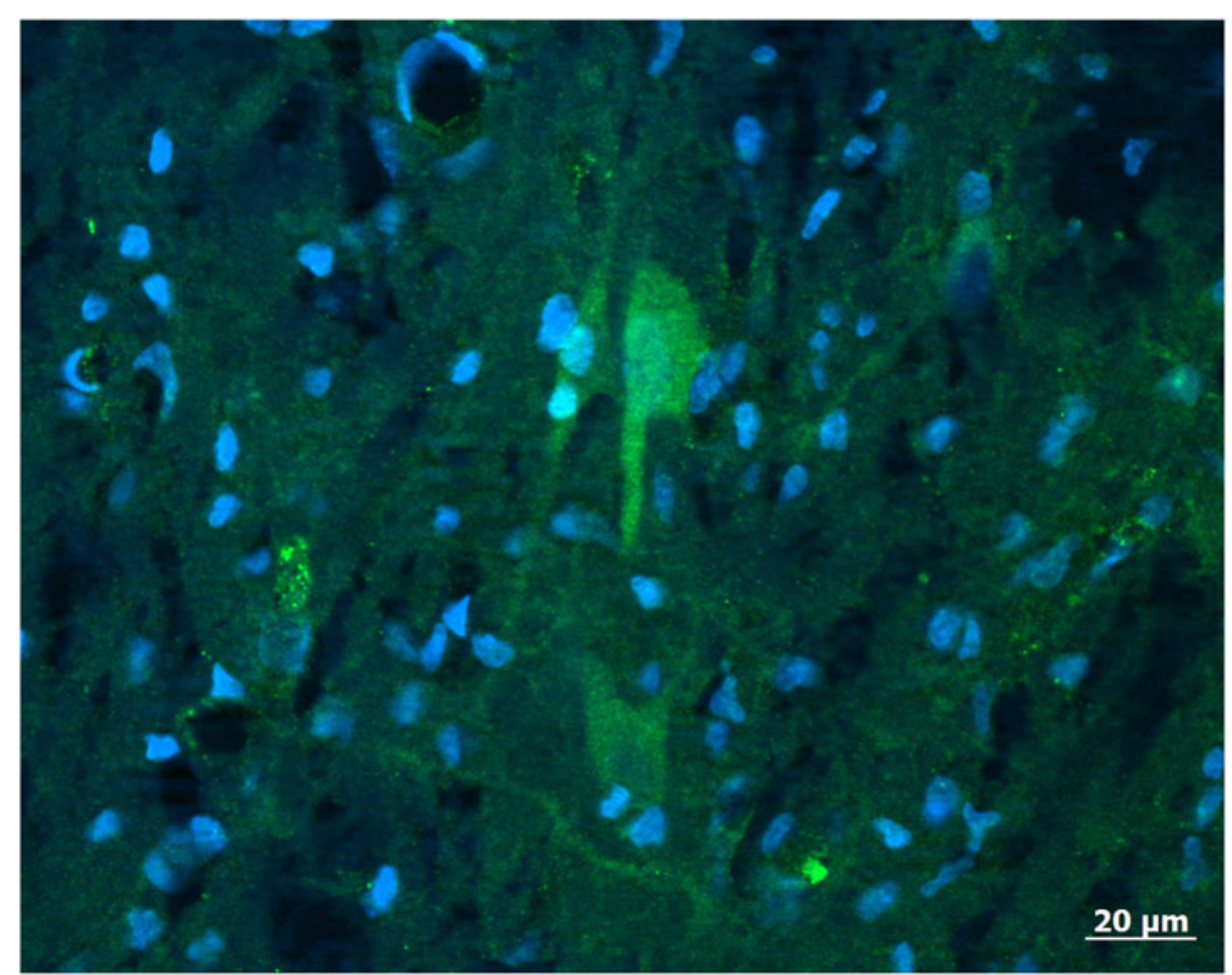

Figure 1 (Colour online) A population of neurons (arrow) positive for kisspeptin (green) and simultaneously counterstained with DAPI (4',6-diamidino-2phenylindolel; blue) to reveal neuronal and glia nuclei were found in the arcuate nucleus of the porcine hypothalamus. The antibody labelled cell body as well as nerve fibres. Image was captured with a Zeiss Axioplan 2 imaging photomicroscope (Carl Zeiss Vision, Oberkochen, Germany) equipped with a digital camera (Axio Cam MRc) and appropriate filters. The captured image was evaluated with the Axio Vision 4.6 Imaging system. For the preparation of microscopic illustrations, Corel Graphic Suite 11 was used only to adjust brightness, contrast and sharpness. Source: CA Lents, unpublished.

et al., 2006; Bedenbaugh et al., 2017), and oestrogen receptor signalling in kisspeptin neurons is critical for the timing of puberty in mice (Mayer et al., 2010). Oestrogen was shown to have profound negative effects on the expression of kisspeptin in the ARC of adult ewes (Smith et al., 2007), demonstrating that hypothalamic expression of kisspeptin is under the influence of gonadal steroids. In prepubertal ewe lambs, the expression of kisspeptin mRNA in the POA, PeV and ARC areas increased with pubertal maturation (Redmond et al., 2011a). The expression of kisspeptin in the ARC was correlated to the age-related increase in LH pulses, suggesting that kisspeptin neurons in this region of the hypothalamus are critical for the pubertal transition in gonadotropin secretion of sheep. This contrasts with the gilt in which the expression of the kisspeptin gene in the PeV region of the hypothalamus was undetectable, by in situ hybridization, during pubertal maturation (from 0 to 5 months of age) (leda et al., 2014). Robust expression of the kisspeptin gene in the ARC of these gilts was observed, but the ARC expression of kisspeptin did not differ with age or puberty status. This finding was corroborated by a recent report that the expression of kisspeptin gene in the MBH of prepubertal, peripubertal or postpubertal luteal phase gilts did not differ (Thorson et al., 2017). Thus, it appears that the pubertal decrease in sensitivity to oestrogen negative feedback in the gilt does not involve changing kisspeptin gene expression. However, it is noted that the gene expression for tachykinin 3 (TAC3), which encodes neurokinin $B$, and the tachykinin 3 receptor
(TAC3R) gene is upregulated in the MBH of peripubertal gilts compared to prepubertal gilts (Thorson et al., 2017). Given the important role of neurokinin $B$, acting through its receptor, to stimulate kisspeptin and LH secretion (Nestor et al., 2012; Goodman et al., 2013), it is speculated that a reduced sensitivity to oestrogen negative feedback and the upregulation of $\mathrm{LH}$ pulse frequency in the gilt involve increased neurokinin B activation of kisspeptin neurons. In this regard, kisspeptin neurons in the ARC are likely critical for pubertal onset in gilts.

Oestrogen has a biphasic effect on LH secretion in pigs. Small developing follicles secrete low levels of oestrogen, which suppresses LH (Kesner et al., 1989). As circulating concentrations of oestrogen secreted from large preovulatory follicles increase, oestrogen acts positively to stimulate an ovulatory surge of LH about $72 \mathrm{~h}$ later (Kraeling et al., 1998). Treating ovariectomized ewes with a kisspeptin receptor antagonist ( $p$-271) abolished the oestrogen-induced surge of LH (Smith et al., 2011), suggesting that kisspeptin is essential for the release of $\mathrm{GnRH}$ necessary to induce the LH surge. In this regard, the upregulation of kisspeptin expression in the $\mathrm{PeV}$ of the gilt may play a critical role in generating oestrogen-induced ovulatory surge of $\mathrm{LH}$ in pigs. When sexually mature ovariectomized gilts were treated with a dose of oestradiol that caused an ovulatory surge of $\mathrm{LH}$, the expression of the kisspeptin gene in the PeV was increased compared to control ovariectomized gilts (Tomikawa et al., 2010). The expression of kisspeptin mRNA in the ARC, 
however, did not differ between oestrogen-treated and control gilts. This implies that discrete subpopulations of kisspeptin neurons in the porcine hypothalamus independently control both surge and tonic secretion of LH.

Kisspeptin receptor gene is expressed in many tissues, including the hypothalamus (Li et al., 2008). The expression of the kisspeptin receptor gene in the porcine hypothalamus differs with stage of the oestrous cycle (Li et al., 2008). Hypothalamic expression of the kisspeptin receptor gene is increased near the time of puberty in rats and primates (Navarro et al., 2004; Shahab et al., 2005). These changes are driven by sex steroids from the maturing gonad. How kisspeptin receptor expression changes with sexual maturity or gonadal steroids in the pig is unknown.

\section{Kisspeptin effects on other reproductive organs}

The receptor for kisspeptin is expressed in the anterior pituitary gland and the gonad of the pig (Li et al., 2008), suggesting a direct effect of kisspeptin on these reproductive tissues. Kisspeptin neural fibres are located in the external zone of the median eminence (ME) of the ewe (Pompolo et al., 2006), and kisspeptin is secreted into the hypophyseal portal vasculature of sheep (Smith et al., 2008b) where it can affect pituitary function. In this regard, kisspeptin stimulated LH secretion from the primary cultures of ovine (Smith et al., 2008b) and porcine (Suzuki et al., 2008) anterior pituitary cells. In the porcine ovary, both kisspeptin and kisspeptin receptor are expressed in the granulosa cells and oocytes of developed follicles (Basini et al., 2018). Kisspeptin may function in the ovary for ovulation and development of the corpus luteum (Peng et al., 2013; Laoharatchatathanin et al., 2015). It was recently reported that kisspeptin improved in vitro development of porcine oocytes (Saadeldin et al., 2018). It is becoming increasingly evident that kisspeptin and its receptor can have important effects on peripheral reproductive tissues. What is unclear is the biological relevance this has for pig reproduction. Nonetheless, direct effects at the level of the anterior pituitary gland or ovary could have important implications in the development and use of kisspeptin or kisspeptin analogues for managing reproduction of gilts and sows.

\section{Kisspeptin and nutritional regulation of reproduction}

\section{Changing energy balance and hypothalamic expression of}

\section{kisspeptin}

It is well established that the initiation of puberty and postpartum reproductive cycles in pigs are metabolically gated. In general, higher growth rates and backfat are positively associated with earlier cyclicity. Limiting dietary energy and amino acids, or feed restriction, even if supplying metabolizable energy above maintenance requirements, delays sexual maturity in gilts (Beltranena et al., 1991; Miller et al., 2011; Calderón Díaz et al., 2017) and decreases LH pulsatility (Prunier et al., 1993; Booth et al., 1996). Gilts of modern genotypes typically exhibit more than adequate growth rates
(Amaral Filha et al., 2009), but these are less fat and are leaner than in previous generations. This may limit their ability to deal with short-term nutritional challenges associated with diet or housing changes. Gilts, in particular, are very sensitive to metabolic shifts, and even short-term energy restrictions ( 7 to 10 days) are sufficient to suppress $\mathrm{LH}$ pulses (Whisnant and Harrell, 2002; Thorson et al., 2018), and realimentation of gilts restores LH pulses in as little as $12 \mathrm{~h}$ (Booth et al., 1996). At issue here is what are the physiological mechanisms that underlie this nutritional regulation of tonic release of $\mathrm{LH}$ in gilts?

Zhou et al. (2014) restricted feed to cyclic gilts for a prolonged period (100 days), to the point that they ceased cycling. Nutritionally induced acyclicity in pigs results from a complete loss of LH pulsatility (Armstrong and Britt, 1987). Using quantitative PCR, it was shown that kisspeptin, kisspeptin receptor and GnRH mRNA expression were all downregulated in the MBH of nutritionally induced acyclic gilts (Zhou et al., 2014). This demonstrates that the negative effects of undernutrition on LH secretion in the pig may be mediated through the suppression of the kisspeptin neuronal system. Long-term undernutrition and prolonged BW loss, however, are not common under typical circumstances. More recently, Thorson et al. (2018) used short-term (10 days) negative energy balance to induce a mild loss in bodyweight that would be similar to what might occur under normal circumstances. In this case, ovariectomized feedrestricted gilts showed reduced frequency and increased amplitude of LH pulses. This change in LH pulse pattern is reflective of a late prepubertal or late lactation LH pulse pattern and would be insufficient to support final maturation and ovulation of ovarian follicles. In this study, in situ hybridization was used to measure the spatial distribution of kisspeptin mRNA expression throughout the entire hypothalamic ARC. No differences in ARC expression of the kisspeptin gene between feed-restricted and full-fed gilts were observed (Thorson et al., 2018). Thus, nutrition-induced changes in LH pulse patterns of gilts can occur without altering the transcription of hypothalamic kisspeptin, which in pigs appears to depend on the duration and magnitude of nutritional restriction.

Feed restriction has been the primary approach to understand nutritional regulation of the reproductive neurosecretory axis in livestock. The converse approach is to feed additional nutrients or energy. In one study, prepubertal gilts were fed either a standard diet formulated to meet the nutritional requirements for gilts $(3.22 \mathrm{MCal} / \mathrm{kg}$ digestible energy, $19.1 \%(P)$ or the standard diet with additional energy in the form of added fat (Zhuo et al., 2014). As would be expected, the gilts fed the higher-energy diet exhibited greater BW gain and accumulation of backfat, resulting in their attaining puberty 12 days earlier than gilts fed the standard diet. When gene expression in the MBH was quantified with $P C R$, no differences in the expression of kisspeptin, kisspeptin receptor or GnRH mRNA were observed in gilts fed standard or high-energy diets. This would be consistent with the observation of Thorson et al. (2018) that modest energy restriction 
Lents

of gilts did not affect ARC expression of kisspeptin. On the other hand, mRNA expressions for kisspeptin and its receptor were upregulated in the hypothalamic tissue containing the caudal POA and PeV of gilts fed a higher-energy diet (Zhuo et al., 2014). The POA of the porcine hypothalamus contains a population of $\mathrm{GnRH}$ neurons that are considered critical for the initiation of pubertal cycles (Kineman et al., 1988). This implies that dietary regulation of pulsatile secretion of $\mathrm{LH}$ in gilts may depend on hypothalamic subpopulations of kisspeptin neurons that respond differently to nutritional signals in regulating the $\mathrm{GnRH}$ pulse generator.

\section{Kisspeptin links leptin with gonadotropin secretion}

A nutritional signal that has important impacts on the reproductive axis of the pig is leptin (Barb et al., 2008; Hausman et al., 2012). Leptin is secreted by adipose tissue and is a key regulator of appetite. Age-related increases in the synthesis and secretion of leptin in the pig (Qian et al., 1999) are associated with increased expression of leptin receptor in the hypothalamus (Lin et al., 2000). Both events are related to increased secretion of $\mathrm{LH}$ during the pubertal escape from oestrogen negative feedback (Barb et al., 2000; Barb et al., 2010a). Furthermore, leptin stimulates the secretion of GnRH from the hypothalamus and LH from the anterior pituitary gland of prepubertal gilts (Barb et al., 2004a). Consequently, leptin is considered a permissive metabolic signal for the initiation of puberty, and indeed, serum concentrations of leptin are genetically correlated with age at puberty in gilts (Kuehn et al., 2009). Thus, leptin acting at the level of the hypothalamus is clearly important for the pubertal increase in pulsatile LH secretion in pigs.

Importantly, GnRH neurons lack leptin receptor (Quennell et al., 2009; Louis et al., 2011), which implies that leptin must affect GnRH secretion indirectly through second- or thirdorder neurons. Leptin receptors are expressed throughout the ARC of the pig hypothalamus (Lin et al., 2001; Czaja et al., 2002b), indicating that kisspeptin neurons in this region may be direct targets for leptin. In this regard, leptin stimulated the firing of kisspeptin neurons in hypothalamic slices of the ARC from guinea pigs (Qiu et al., 2011). Although this is strong evidence for a direct effect of leptin on kisspeptin neurons, other studies have called this assumption into question. It was reported that few kisspeptin cells in the hypothalamus of mice or sheep co-localized with STAT3 (Louis et al., 2011; Quennell et al., 2011), the major intracellular signalling molecule induced by leptin acting at its receptor. These and other studies have led to the general conclusion that leptin probably affects the secretion of $\mathrm{GnRH}$ through other neuronal systems, such as neuropeptide Y (NPY).

Neuropeptide $Y$ is an orexigenic neuropeptide that is negatively regulated by leptin. Leptin receptor is co-localized with NPY neurons in the pig (Czaja et al., 2002a), demonstrating that NPY is a primary target for leptin in the porcine hypothalamus. When pigs received ICV injections of leptin, it suppressed the stimulatory effect of NPY on food intake (Barb et al., 2006). Furthermore, the pulsatile secretion of LH in gilts is strongly suppressed by NPY (Barb et al., 2006). This implies that leptin-induced reduction in NPY is important for increased LH pulses in gilts. Between $30 \%$ and $60 \%$ of kisspeptin cells in the ARC of sheep and cattle are in close apposition to NPY fibres (Backholer et al., 2010; Alves et al., 2015), suggesting that NPY might directly suppress kisspeptin neurons to affect GnRH secretion. Fibres for NPY are also in close contact with GnRH neurons in the POA and MBH of heifers (Alves et al., 2015). When the heifers were fed a high-energy diet that promoted an early age at puberty, the proportion of $\mathrm{GnRH}$ neurons contacted by NPY fibres in the MBH were reduced compared with heifers fed a low-energy diet; however, diet did not alter the number of kisspeptin neurons contacted by NPY dendrites (Alves et al., 2015). These data are interpreted to mean that when circulating concentrations of leptin are low, the expression of NPY is upregulated and suppresses the pulsatile secretion of $\mathrm{LH}$ by acting to directly inhibit $\mathrm{GnRH}$ release. The suppression of GnRH secretion by NPY may be further amplified by its inhibition of kisspeptin neurons, which attenuates kisspeptin-stimulated release of GnRH. The prepubertal rise of leptin in pigs likely suppresses the negative NPY tone and permits the transition to a higher LH pulse frequency for the initiation of puberty and reproductive cycles (Figure 2).

Increasing leptin suppresses feed intake not only by lessening NPY action but also by upregulating proopiomelanocortin (POMC) neurons in the hypothalamus (Barb et al., 2008). The POMC gene produces the alpha-melanocyte-stimulating hormone ( $\boldsymbol{\alpha}$-MSH), which, acting at melanocortin-3 and -4 receptors, is anorexigenic in pigs (Barb et al., 2010b). The ARC of the porcine hypothalamus contains dense populations of POMC-expressing cells that project neural fibres rostrally to the POA and anterior hypothalamic area (AHA) (Kineman et al., 1989) where GnRH neurons are found. This indicates a strong possibility for POMC to affect GnRH release in pigs directly or indirectly through kisspeptin neurons in the ARC. Many kisspeptin cells in the ARC of sheep and cattle are in close contact with POMC neuronal fibres (Backholer et al., 2010; Cardoso et al., 2015). Feeding heifers a high-energy diet, which reduced the age of first oestrus, resulted in greater circulating concentrations of leptin, greater expression of $\alpha-\mathrm{MSH}$ in the ARC and more kisspeptin cells being contacted by POMC fibres (Cardoso et al., 2015). These results suggest that increased signalling from POMC to kisspeptin neurons stimulates increased GnRH secretion for puberty in heifers. In support of this, treating ewes in the luteal phase of the oestrous cycle with a melanocortin agonist (MTII) increased POA expression of kisspeptin, which was accompanied by increased LH pulsatility (Backholer et al., 2009). Whether the same relationship between kisspeptin and POMC neurons exists in the pig is unknown. There are distinct structural differences in the distribution of POMC neurons in pigs compared with ruminants. Unlike cattle (Leshin et al., 1988), for example, pigs do not exhibit POMC fibres in the external zone of the ME (Kineman et al., 1989). Treating gilts with a melanocortin antagonist (SHU9119) or a 

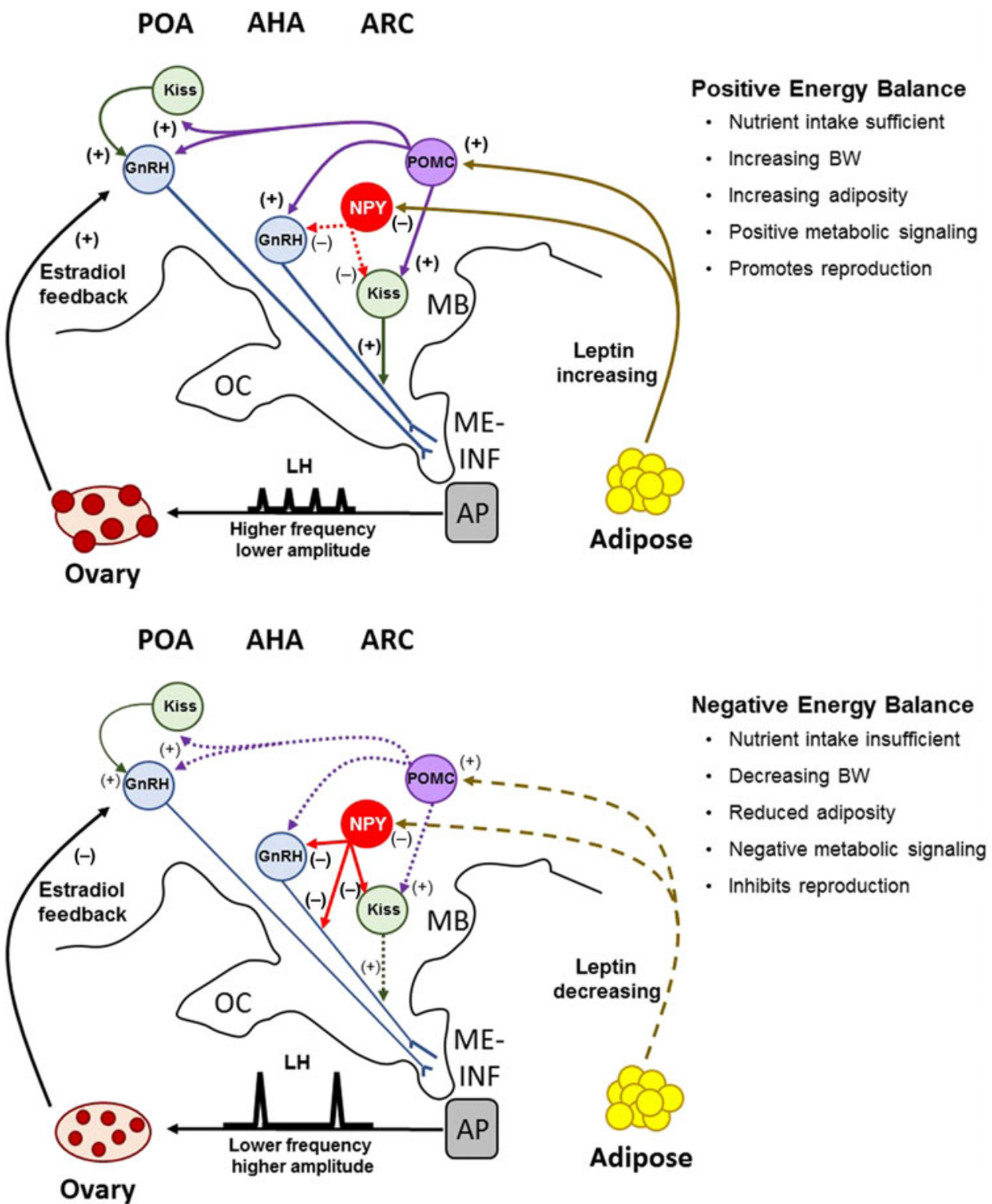

Figure 2 (colour online) A model depicting the proposed role of Kiss, NPY and POMC neuronal pathways and their regulation of GnRH secretion during positive and negative energy balance in the pig. Positive energy balance, characterized by nutrient sufficiency, is signalled to the hypothalamus by NPY and POMC cells in the ARC, which act as metabolic sensors for the activation of GnRH secretion. Increasing leptin inhibits the negative effects of NPY on GnRH and Kiss neurons, and upregulates the activation of POMC cells, which project axonal fibres rostrally to the POA and AHA. These afferent projections are predicted to impact both Kiss and GnRH expression cells in the POA and ARC, thus driving increased secretion of GnRH for high-frequency, low-amplitude pulses that promote ovarian follicular growth and maturation. During negative energy balance, leptin is reduced and lessens the excitatory signal (POMC) and increases the inhibitory signal (NPY). Remodelling of neuronal projections from NPY to GnRH neurons inhibit GnRH release for high-amplitude, low-frequency LH pulses that limit the maturation of ovarian follicles. The inhibitory signal of NPY to GnRH secretion is amplified by its inhibition of Kiss neuronal stimulation of GnRH secretion. These neuronal systems are sensitive to feedback from ovarian oestradiol, which switches from one of positive influence to one of negative influence when leptin concentrations are decreasing. $\mathrm{OC}=$ optic chiasm; $\mathrm{MB}=$ mammillary body; $\mathrm{ME}=$ median eminence; $\mathrm{INF}=$ infundibulum; $\mathrm{AP}=$ anterior pituitary gland; Kiss=kisspeptin; NPY=neuropeptide $Y ; P O M C=$ proopiomelanocortin; $\mathrm{GnRH}=$ gonadotropin-releasing hormone; $\mathrm{ARC}=$ arcuate nucleus; $\mathrm{AHA}=$ anterior hypothalamic area; POA=preoptic area.

melanocortin agonist (NDP-MSH) failed to affect LH secretion (Barb et al., 2004b). Caution should be used when interpreting these results because gilts were ovariectomized. Thus, whether POMC signalling at kisspeptin or $\mathrm{GnRH}$ neurons in the hypothalamus is related to the pubertal transition in pulsatile secretion of $\mathrm{LH}$ in gilts remains to be fully answered.

\section{Kisspeptin and genetic control of fertility}

A role for kisspeptin in reproduction did not become evident until it was discovered that some patients with hypogonadal hypogonadism $(\mathbf{H H})$ harboured mutations in the gene for kisspeptin receptor (de Roux et al., 2003; Seminara et al., 2003; Semple et al., 2005). Cases of HH are characterized by a lack of gonadal development and low levels of 
Lents

gonadotropin secretion from the anterior pituitary gland. Individuals with $\mathrm{HH}$ arising from mutations in the kisspeptin receptor gene failed to transition through puberty. Patients with $\mathrm{HH}$ displayed gonadal responsiveness to treatment with exogenous gonadotropin. Moreover, the secretion of endogenous gonadotropins could be restored when individuals were treated with GnRH (Seminara et al., 2003). Mouse models were developed in which the gene for kisspeptin or its receptor were knocked out (Funes et al., 2003; Seminara et al., 2003; d'Anglemont de Tassigny et al., 2007; Lapatto et al., 2007). Indeed, these mice recapitulated the $\mathrm{HH}$ phenotype and failed to become pubertal. Males had small testes with no sperm production, reduced sex steroids and lacked the development of secondary sex characteristics. Female kisspeptin receptor-knockout mice failed to have normal ovarian follicular maturation or to become pregnant upon exposure to fertile males. Despite being hypogonadotropic, these mice had normal levels of GnRH in the hypothalamus and a normative response to exogenous $\mathrm{GnRH}$. Other than an infertile phenotype, these mice were completely normal.

Genetically modified large animal models for the study of the kisspeptin system did not exist until 2016 when pigs that contained an edit in the kisspeptin receptor gene were developed (Sonstegard et al., 2016). Boars were produced through somatic cell nuclear transfer using cell lines from White Composite pigs that had been genetically edited with TALen gene editing techniques. The gene edit introduced a premature stop codon in the third exon to create a kisspeptin receptor knockout. The kisspeptin receptor-knockout pig produced a similar hypogonadal phenotype to that observed in mouse knockout models. Histological analysis revealed the formation of seminiferous tubules in the testes; however, no sperm was observed in the lumen of these tubules. The lack of sperm production was presumed to be a consequence of hypogonadotropism as indicated by low circulating concentrations of testosterone $(0.20$ to $0.25 \mathrm{ng} / \mathrm{ml})$. Results from Sonstegard et al. (2016) unequivocally demonstrated that kisspeptin neuronal signalling in the hypothalamus is essential for sexual maturation in the pig.

Kisspeptin receptor-knockout boars were noted as being phenotypically normal with similar behaviour and growth as barrow pigs. Although intact, the low androgen production from kisspeptin receptor-knockout boars indicates that their risk of developing boar taint would be low. The possibility of utilizing pigs that are edited for kisspeptin or its receptor for pork production has been postulated (Sonstegard et al., 2017), and there would be an obvious advantage from an animal welfare standpoint; pigs would not be subjected to castration. Beyond regulatory concerns is the obvious practical challenge of how to produce pigs at a commercial scale from animals with a gene edit that produces an infertile phenotype. When kisspeptin receptor-knockout pigs were treated with either exogenous gonadotropin hormones (both $\mathrm{LH}$ and FSH) or GnRH to initiate testicular development, testicular size increased over $200 \%$ compared to sham-treated kisspeptin-knockout boars (Sonstegard et al., 2016). Despite histological evidence that testes of hormone-treated knockout boars could potentially support sperm production, no sperm were produced. This illustrates that managing the reproductive phenotype of kisspeptin receptor-knockout pigs will not be straightforward. Does postnatal proliferation of Sertoli cells in these pigs occur to support normal sperm production? Is the spermatogonial stem cell niche in these pigs properly established? These and other important questions will have to be addressed before genetic manipulation of the kisspeptin system for pork production could become practical. Nonetheless, these types of genetically modified pig models hold tremendous potential as a scientific tool to gain new insights into the reproductive development of pigs that could lead to new discoveries to improve pork production.

Genome-wide association studies have been conducted for delayed puberty and age at puberty in White crossbred and composite maternal lines of pigs (Tart et al., 2013; Nonneman et al., 2014 and 2016). Several genomic regions containing genes regulating growth, adiposity and neural function were identified; however, genomic associations for regions containing kisspeptin or its receptor were not identified. Using a genetic resource population developed from White Duroc $\times$ Chinese Erhualian crossbred pigs, Li et al. (2008) identified a number of polymorphisms in the kisspeptin receptor gene. Many of the alleles were fixed or occurred at a higher frequency in Chinese breeds than in Western breeds. Five different haplotypes for polymorphic sites within the kisspeptin receptor gene with frequencies greater than 0.01 were evaluated for association with age at puberty, but no significant association was detected, despite substantial variance in age at puberty within the population. Phenotypic associations for genetic variants that occur at low allele frequency are not easily detected in typical genomic analyses. Functional variants in kisspeptin receptor with deleterious effects would result in complete or substantial infertility and would not likely increase in allele frequency because gilts and boars harbouring such mutations would be quickly culled from the herd. In the case of the kisspeptin gene, it is small and nucleotide variation in the coding sequence is rare. The few kisspeptin sequence variants that have been found in humans are typically monoallelic, and in rare instances these are associated with a reproductive condition, these are more typically associated with precocious puberty rather than hypogonadotropism (De Guillebon et al., 2011). Thus, it is unlikely that adequate genetic diversity exists in kisspeptin or kisspeptin receptor genes for genetic selection to improve gilt and sow fertility.

\section{Use of kisspeptin and kisspeptin analogues for pharmacological control of reproductive cycles}

The potential for kisspeptin to be useful in managing reproductive cycles and ovulation in livestock is obvious. The bulk of the work in this area has been conducted in sheep (Redmond et al., 2011b) with a few studies in cattle (Whitlock et al., 2008; Ezzat Ahmed et al., 2009) and mares 
(Magee et al., 2009; Decourt et al., 2014). These studies encompass a wide range of differences in seasonality, presence of gonadal steroid feedback, stage of the ovarian cycle and state of sexual maturation that must be taken into careful consideration when comparing studies. In general, IV injection of kisspeptin at doses ranging from 0.75 to 5 $\mathrm{nmol} / \mathrm{kg}$ induce a surge-like release of $\mathrm{LH}$ in cattle and sheep (Caraty et al., 2007a; Whitlock et al., 2008; Redmond et al., 2011b). Endocrine changes for prepubertal gilts treated with approximately 11.4 to $56.9 \mathrm{nmol} / \mathrm{kg}$ (768 to $3839 \mathrm{nmol}$ per gilt) of kisspeptin have been reported (Lents et al., 2008) and are similar to those observed in other species. All doses of kisspeptin induced a surge-like release of LH. The 11.4 $\mathrm{nmol} / \mathrm{kg}$ dose of kisspeptin is probably maximal in pigs as there was no further increase in LH secretion beyond this dose. Regardless of treatment dose, the pulse of LH was transient, lasting for about $1.5 \mathrm{~h}$ before returning to baseline due to the short half-life ( $<60 \mathrm{~s}$ ) of kisspeptin in serum. Moreover, FSH secretion in these gilts was not effectively stimulated by IV treatment with kisspeptin. These data were recently corroborated when it was reported that IV treatment of 18-week-old gilts with kisspeptin at even higher doses (3839 and $7678 \mathrm{nmol}$ per gilt) induced similar secretory profiles of LH (Ralph et al., 2017). The secretory profile of gonadotropins in prepubertal gilts treated with a single injection of kisspeptin would not be expected to affect ovarian follicular growth sufficiently to lead to oestrus and ovulation.

To sustain the secretion of gonadotropin hormones, repeated injections of kisspeptin are required. Repeated injections of kisspeptin to ovariectomized (Caraty et al., 2007a) or seasonally anoestrous ewes (Caraty et al., 2013) resulted in repeatable pulses of $\mathrm{LH}$, but no effects on FSH. Similar results were obtained in prepubertal ewe lambs treated every hour for $24 \mathrm{~h}$ (Redmond et al., 2011b). An LH surge occurred at about $17 \mathrm{~h}$ after the start of treatment in four of the six kisspeptin-treated lambs and resulted in ovulation. These lambs failed to maintain corpora lutea, suggesting that gonadotropin output after cessation of kisspeptin treatment was not adequate for luteotropic support. Sufficient sexual maturation in females must occur such that the GnRH pulse generator can be sustained to make kisspeptin treatment useful in prepubertal animals. The other approach that has been tested is to continuously infuse kisspeptin. In adult ovariectomized (Caraty et al., 2007a) or anoestrous ewes (Caraty et al., 2007a; Sebert et al., 2010), continuous infusion resulted in an initial increase in $\mathrm{LH}$ secretion followed by an ovulatory surge of $\mathrm{LH}$ between 15 and $30 \mathrm{~h}$ later. Approximately $80 \%$ of kisspeptin-treated ewes ovulated. The initial kisspeptin-induced increase in $\mathrm{LH}$ and FSH was followed subsequently by increasing the concentrations of oestradiol from developing follicles that were critical for the induction of the subsequent LH surge. Similar increases in LH and FSH were seen with kisspeptin treatment in the mare, but kisspeptin failed to stimulate ovulation (Magee et al., 2009; Decourt et al., 2014). Important differences between mares and ewes are that mares are oestrus for a longer duration, the timing of the ovulatory LH surge relative to the start of oestrus is more variable, and the LH surge is more protracted. There have been no studies in pigs evaluating the effect of sustained infusion of kisspeptin on inducing an LH surge or ovulation; however, it is noted that a long duration of oestrus and variable timing of the LH surge relative to the onset of oestrus and ovulation in pigs is similar to that of the mare. This highlights the important need for species-specific studies in kisspeptin research.

Repeated injections or chronic infusion are not practical for the reproductive management of livestock. Some researchers have tried to alter kisspeptin to increase its half-life or potency to overcome this issue. This approach was successful for GnRH but has proven to be less useful for kisspeptin. There are some kisspeptin analogues that have been developed and tested for their ability to control reproduction in livestock (Table 1). The effects of kisspeptin analogue TAK683 (kisspeptin receptor agonist; Ac-[D-Tyr46, D-Trp47,Thr49, azaGly51,Arg(Me)53,Trp54]metastin(46-54)) on LH have been extensively characterized in goats. Small doses $(3.5 \mathrm{nmol})$ given IV or SC to cyclic does after the removal of a progesterone device (CIDR) resulted in elevated concentrations of LH for $10 \mathrm{~h}$ (Kanai et al., 2017). The SC treatment resulted in a preovulatory increase in oestradiol and advanced ovulation by 3 days. In ovariectomized does, TAK683 had minimal (Goto et al., 2014) to no effect (Kanai et al., 2017) on LH secretion, which highlights the importance of ovarian steroids in modulating the effects of kisspeptin analogues. Other studies reported that IV injections of $35 \mathrm{nmol}$ of TAK683 induced surges of LH lasting 6 to $12 \mathrm{~h}$ in follicular and luteal-phase does (Endo et al., 2015). The timing of oestradiol changes associated with TAK683 injection depended upon the phase of oestrous cycle at the time of treatment, but ovulation was induced in five of five does and four of five does when TAK683 treatment was initiated in the follicular and luteal phase of the oestrous cycle, respectively. The magnitude of $\mathrm{LH}$ release induced by TAK683 was greater when does were treated in the follicular phase (Endo et al., 2015) than in the luteal phase (Endo et al., 2015; Rahayu et al., 2017).

Although these data would support the expectation that TAK683 could be useful for inducing or timing ovulation in livestock, there are negative effects. The TAK683 molecule was developed as a kisspeptin receptor antagonist. After the initial increase in LH secretion, TAK683 suppresses LH pulsatility and circulating concentrations of LH within $24 \mathrm{~h}$ from the start of treatment (Yamamura et al., 2014). Pulsatile secretion of $\mathrm{LH}$ was completely abolished in ovariectomized does treated with a 5-day SC infusion $(500 \mathrm{nmol} / \mathrm{kg})$ of TAK683. This effect has intriguing potential for managing reproduction in pigs. Altrenogest is the only approved product available to prevent oestrus and ovulation in pigs and is used extensively to synchronize oestrus. Kisspeptin antagonists could be a useful alternative because pituitary responsiveness to GnRH remains intact. Chronic SC infusion of TAK683 appears to abolish LH pulses in goats without affecting the GnRH pulse generator (Yamamura et al., 2014). However, there may be negative effects on ovarian follicles 


\begin{tabular}{|c|c|c|c|c|c|c|c|c|}
\hline \multirow[b]{2}{*}{ Species (sex) } & \multirow[b]{2}{*}{ Reproductive status } & \multirow[b]{2}{*}{ Compound } & \multirow[b]{2}{*}{ Dose } & \multicolumn{4}{|c|}{ Effects on } & \multirow[b]{2}{*}{ References } \\
\hline & & & & LH (duration) & FSH (duration) & Gonadal steroids & Ovulation & \\
\hline Goat (doe) & Adult OVX & TAK683 & $5 \mu \mathrm{g}, \mathrm{IV}$ & No effect & Not reported & & & Kanai et al. (2017) \\
\hline Goat (doe) & Cyclic adult, synchronized & TAK683 & $5 \mu \mathrm{g}, \mathrm{IV}, \mathrm{SC}$ & Increased (10 h) & Not reported & Initial increase & $\begin{array}{l}\text { Advanced } 3 \\
\text { days }\end{array}$ & Kanai et al. (2017) \\
\hline Goat (doe) & Adult OVX & TAK683 & $\begin{array}{l}500 \mathrm{nmol} / \mathrm{kg} \\
\text { per week, SC }\end{array}$ & Abolished LH pulses & Not reported & & & Tanaka et al. (2013) \\
\hline Goat (doe) & Adult OVX & TAK683 & $35 \mathrm{nmol}, \mathrm{IV}$ & Increase (4 h) & Not reported & & & Goto et al. (2014) \\
\hline Goat (doe) & Adult cyclic, synchronized & TAK683 & $35 \mathrm{nmol}, \mathrm{IV}$ & Increased (6 h) & Increased (6 h) & $\begin{array}{l}\text { Immediate } \\
\text { suppression }\end{array}$ & 3 of 4 & Goto et al. (2014) \\
\hline Goat (doe) & Adult cyclic, synchronized & TAK683 & $35 \mathrm{nmol}, \mathrm{IV}$ & Immediate surge $(8 \mathrm{~h})$ & Not reported & Supressed after $6 \mathrm{~h}$ & 5 of 5 & Endo et al. (2015) \\
\hline Goat (doe) & Adult cyclic, day 3 of CIDR & TAK683 & $35 \mathrm{nmol}, \mathrm{IV}$ & Increased at $12 \mathrm{~h}$ & Not reported & Increased after $6 \mathrm{~h}$ & 4 of 5 & Endo et al. (2015) \\
\hline Goat (doe) & Adult cyclic, day 5 luteal & TAK683 & $35 \mathrm{nmol}, \mathrm{IV}$ & Increased by $14 \mathrm{~h}$ & Not reported & Increased with LH & & Rahayu et al. (2017) \\
\hline Goat (doe) & Adult cyclic, day 9 luteal & TAK683 & $35 \mathrm{nmol}, \mathrm{IV}$ & Minimal increase & Not reported & No effect & & Rahayu et al. (2017) \\
\hline Sheep (ewe) & Adult noncyclic & FTM080 & $\begin{array}{l}0.5,2.5,5 \mathrm{nmol}, \\
\quad \text { IV }\end{array}$ & Increased $<1 \mathrm{~h}$ & & & & Whitlock et al. (2015) \\
\hline Sheep (ewe) & Adult noncyclic & $\mathrm{C} 17$ & $15 \mathrm{nmol}, \mathrm{IM}$ & Increased (9 h) & Increased (5 h) & & & Beltramo et al. (2015 \\
\hline Sheep (ewe) & Adult cyclic, synchronized & $\mathrm{C} 6$ & $15 \mathrm{nmol}, \mathrm{IM}$ & Increased $(10 \mathrm{~h})$ & $\begin{array}{l}\text { Increased }(5 \mathrm{~h}) \text {, } \\
\text { again } 24 \mathrm{~h} \\
\text { later }\end{array}$ & & 12 of 12 & Decourt et al. (2016) \\
\hline Sheep (ewe) & Adult noncyclic, progestin primed & $\mathrm{C6}$ & $15 \mathrm{nmol}, \mathrm{IM}$ & Increased (12 h) & Not reported & & 8 of 12 & Decourt et al. (2016) \\
\hline Sheep (ram) & Adult & $\mathrm{C} 6$ & $15 \mathrm{nmol}, \mathrm{IM}$ & Increased (10 h) & Not reported & Increased $>12 \mathrm{~h}$ & & $\begin{array}{l}\text { Beltramo and Decour } \\
(2018)\end{array}$ \\
\hline Cattle (bull) & Prepubertal & $\mathrm{C6}$ & $\begin{array}{l}20 \text { nmol, IM, } \\
\text { daily, } \\
4 \text { days }\end{array}$ & $\begin{array}{l}\text { Day } 1 \text {, increased } \\
(5 \mathrm{~h}) ; \text { day } 4 \text {, subacute }\end{array}$ & No effect & No effect & & Parker et al. (2019) \\
\hline Pig (gilt) & $\begin{array}{l}\text { Prepubertal, after PG600 and } \\
\text { Matrix }\end{array}$ & C6 & $60 \mathrm{nmol}, \mathrm{IM}$ & Increased (>16 h) & & & 5 of 7 & Ralph et al. (2018) \\
\hline
\end{tabular}


at subsequent ovulations. Goto et al. (2014) reported that ovulations induced in cyclic does with TAK683 resulted in lower levels of progesterone during the luteal cycle. Moreover, the emergence of new follicles was delayed in these goats. Consequently, they ovulated smaller, less mature follicles in the subsequent oestrous cycle, which would be expected to reduce fertility. These and other issues will need to be addressed for the effective use of such kisspeptin antagonists in pork production.

Another well-characterized compound is the kisspeptin receptor agonist C6 (Palm- $\gamma$-Glu-Tyr-Asn-Trp-Asn-Ser-PheGlyw[Tz]Leu-Arg(Me)-Tyr-NH2). In adult rams, i.m. injections of C6 (15 nmol) resulted in a sustained (10 h) increase in circulating concentrations of $\mathrm{LH}$ that were accompanied by elevated concentrations of testosterone (Beltramo and Decourt, 2018). Prepubertal bulls treated with C6 exhibited greater secretion of LH lasting $6 \mathrm{~h}$, but FSH and testosterone were unaffected (Parker et al., 2019). This may indicate that adequate pubertal development must occur in bulls to achieve the expected gonadal response. Moreover, repeated injections of C6 to prepubertal bulls for 4 days resulted in a loss of LH secretory response to treatment, possibly resulting from kisspeptin receptor desensitization. In adult acyclic ewes primed with progesterone or in cyclic ewes, a single IM injection of $\mathrm{C} 6$ resulted in an increase in LH secretion lasting 10 to $12 \mathrm{~h}$ (Decourt et al., 2016). This treatment in cyclic ewes resulted in an initial surge-like release of FSH followed by a sustained increase in the secretion of FSH, such as would follow ovulation, approximately $24 \mathrm{~h}$ after $\mathrm{C} 6$ treatment started. Indeed, all 12 of the cyclic ewes treated with C6 ovulated, and 8 of 12 noncyclic ewes ovulated in response to $\mathrm{C} 6$ treatment. A preliminary report indicated that a single IM injection of C6 to 18-week-old gilts caused a sustained increase in LH secretion resulting in ovulation in five of seven gilts (Ralph et al., 2018). In this case, gilts had been primed with human chorionic and pregnant mare serum gonadotropin followed by altrenogest such that adequate follicle development was present for ovulation to occur. It is not clear if C6 may be useful for stimulating oestrus and ovulation in non-steroid-primed prepubertal gilts or postpartum sows. Nonetheless, the results point to a real possibility that kisspeptin analogues could be developed for the control of reproduction in pigs.

\section{Is kisspeptin involved in seasonal infertility of swine?}

In the northern hemisphere, seasonal decreases in fertility are evident in commercial swine. This seasonal infertility is a decrease in the reproductive performance of pigs during summer and early fall (July, August, September) that manifests as reduced farrowing rates during the winter months (November, December, January). In the southern hemisphere, decreased farrowing rates are observed in late summer to early autumn. Seasonal infertility usually affects $5 \%$ to $10 \%$ of breeding females, but this can be as high as $25 \%$ in some geographical locations or production systems. The summer decrease in reproductive performance of pigs is generally characterized by decreased cyclicity of replacement gilts, increased wean to oestrus intervals of sows, increased loss of pregnancy and reduced litter size, with gilts and first parity sows being most affected (Tummaruk et al., 2007; Bloemhof et al., 2013). It must be noted that seasonal infertility is an issue affecting all geographical regions of pork production and a wide array of management and housing systems. Many risk factors, including heat stress, nutritional stress, immune function, ovarian function, uterine function, and others, have been linked to seasonal infertility of pigs, which illustrates the extremely complex aetiology of the problem. The discussion that follows is highly focused. For a broader perspective, the reader is referred to more comprehensive reviews (Love et al., 1993; Peltoniemi and Virolainen, 2006; Bertoldo et al., 2012; De Rensis et al., 2017).

It is generally concluded that seasonal infertility in swine involves, to some extent, inadequate gonadotropin secretion. Reduced GnRH, LH and FSH in weaned sows has been reported during summer months (Armstrong et al., 1986). The reason for this is not fully understood, but it is speculated to be related to increased sensitivity to oestradiol negative feedback during summer months. The suppressive effect of oestradiol on basal concentrations of LH and LH pulse amplitude of gilts, however, was greater during short-day photoperiod than in long-day photoperiod (see Love et al., 1993). Further, season had little to no effect on the LH secretory response of ovariectomized gilts treated with low or high levels of oestradiol, nor was there a season $\times$ oestradiol interaction on the response of gilts to exogenous GnRH (Cox et al., 1987; Smith et al., 1991). Seasonally anoestrus weaned primiparous sows responded normally to pulsatile treatment with GnRH (Armstrong and Britt, 1985), exogenous oestradiol (Cox et al., 1983) and gonadotropin hormones (Britt et al., 1986), suggesting that the hypothalamic-pituitaryovarian-axis of sows remains fully functional during summer months. These data indicate that any potential seasonal effect on gonadotropin secretion in the pig lies upstream of $\mathrm{GnRH}$, but seasonal responses to oestradiol feedback are yet to be fully resolved.

Seasonal acyclicity exhibited by caprine and ovine species is determined by increases in daylength that result in an increase in sensitivity to oestrogen negative feedback and molecular changes in the expression of kisspeptin in the hypothalamus associated with a reduced frequency of $\mathrm{LH}$ pulses (Smith et al., 2007; Smith et al., 2008a). Seasonal infertility of domestic swine coincides with the nonbreeding season of Eurasian wild boar (Mauget, 1982), and it has been proposed that the kisspeptin neuronal system may underlie seasonal differences in gonadotropin secretion of domestic sows (De Rensis et al., 2017). There have been no published studies evaluating the effect of season, photoperiod or melatonin on kisspeptin function in pigs; so this hypothesis remains to be tested. It is difficult to unravel the confounding of seasonal changes in temperature and photoperiod, but these factors can have independent effects on sow fertility (Tantasuparuk et al., 2000; Sevillano et al., 2016) (Auvigne et al., 2010). Regardless, seasonal effects on LH seem to 
be largely related to a suppression of feed intake and its associated metabolic state. As discussed above, fluctuations in nutrient intake seem to have little effect on the expression of kisspeptin mRNA unless nutritional restriction is severe and prolonged. Whether differences in feed intake are affecting the transcription and expression of kisspeptin protein, however, remain to be determined. Administering kisspeptin or its analogues to seasonal anoestrous ewes overcomes the seasonal inhibition of $\mathrm{LH}$ secretion leading to ovulation (Caraty et al., 2007a; Sebert et al., 2010; Decourt et al., 2016). It is expected that as kisspeptin analogues become developed and optimized for use in swine, these will be useful tools for mitigating seasonal effects on sow fertility.

\section{Conclusion}

Strong evidence has accumulated that kisspeptin is a critical component in the regulation of gonadotropin secretion and reproduction in swine. Anatomical distribution of the kisspeptin neuronal system is organized similarly in the pig as other species, but there are clear differences in its regulation, particularly from gonadal steroids. In this regard, research on the role of kisspeptin in regulating reproductive biology of pigs has lagged that of other livestock species, particularly sheep and goats. This is a critical area of need going forward because of the distinct physiological differences between species. Kisspeptin and kisspeptin analogues demonstrate promise for use in managing reproductive cycles and ovulation in pigs. However, pig-specific research is needed to optimize the use of such compounds for a precise control of fertility in pork production.

\section{Acknowledgements}

None.

\section{Declaration of interest}

Mention of trade names or commercial products in this publication is solely for the purpose of providing specific information and does not imply recommendation or endorsement by the USDA. The USDA prohibits discrimination in all its programs and activities on the basis of race, colour, national origin, age, disability, and where applicable, sex, marital status, familial status, parental status, religion, sexual orientation, genetic information, political beliefs, reprisal, or because all or part of an individual's income is derived from any public assistance program. (Not all prohibited bases apply to all programs.) Persons with disabilities who require alternative means for communication of program information (Braille, large print, audiotape, etc.) should contact USDA's TARGET Center at (202) 720-2600 (voice and TDD). To file a complaint of discrimination, write to USDA, Director, Office of Civil Rights, 1400 Independence Avenue, S.W., Washington, DC 20250-9410, or call (800) 795-3272 (voice) or (202) 720-6382 (TDD). USDA is an equal opportunity provider and employer.

\section{Ethics statement}

No relevant information to declare for review article.

\section{Software and data repository resources}

None of the data were deposited in an official repository.

\section{References}

Alves BR, Cardoso RC, Prezotto LD, Thorson JF, Bedenbaugh M, Sharpton SM, Caraty A, Keisler DH, Tedeschi LO, Williams GL and Amstalden M 2015. Elevated body weight gain during the juvenile period alters neuropeptide Y-gonadotropin-releasing hormone circuitry in prepubertal heifers. Biology of Reproduction 92, 46.

Amaral Filha WS, Bernardi ML, Wentz I and Bortolozzo FP 2009. Growth rate and age at boar exposure as factors influencing gilt puberty. Livestock Science 120, 51-57.

Armstrong JD and Britt JH 1985. Pulsatile administration of gonadotropinreleasing hormone to anestrous sows: endocrine changes associated with GnRH-induced and spontaneous estrus. Biology of Reproduction 33, 375-380. Armstrong JD and Britt JH 1987. Nutritionally-induced anestrus in gilts: metabolic and endocrine changes associated with cessation and resumption of estrous cycles. Journal of Animal Science 65, 508-523.

Armstrong JD, Britt JH and Cox NM 1986. Seasonal differences in function of the hypothalamic-hypophysial-ovarian axis in weaned primiparous sows. Journal of Reproduction and Fertility 78, 11-20.

Arreguin-Arevalo JA, Lents CA, Farmerie TA, Nett TM and Clay CM 2007. KiSS-1 peptide induces release of LH by a direct effect on the hypothalamus of ovariectomized ewes. Animal Reproduction Science 101, 265-275.

Auvigne V, Leneveu P, Jehannin C, Peltoniemi $O$ and Sallé E 2010. Seasonal infertility in sows: a five year field study to analyze the relative roles of heat stress and photoperiod. Theriogenology 74, 60-66.

Backholer K, Smith J and Clarke IJ 2009. Melanocortins may stimulate reproduction by activating orexin neurons in the dorsomedial hypothalamus and kisspeptin neurons in the preoptic area of the ewe. Endocrinology 150, 5488-5497.

Backholer K, Smith JT, Rao A, Pereira A, Iqbal J, Ogawa S and Clarke IJ 2010. Kisspeptin cells in the ewe brain respond to leptin and communicate with neuropeptide $Y$ and proopiomelanocortin cells. Endocrinology 151, 2233-2243. Barb CR, Barrett JB and Kraeling RR 2004a. Role of leptin in modulating the hypothalamic-pituitary axis and luteinizing hormone secretion in the prepuberal gilt. Domestic Animal Endocrinology 26, 201-214.

Barb CR, Estienne MJ, Kraeling RR, Marple DN, Rampacek GB, Rahe CH and Sartin JL 1991. Endocrine changes in sows exposed to elevated ambient temperature during lactation. Domestic Animal Endocrinology 8, 117-127.

Barb CR, Hausman GJ and Kraeling RR 2010a. Luteinizing hormone secretion as influenced by age and estradiol in the prepubertal gilt. Animal Reproduction Science 122, 324-327.

Barb CR, Hausman GJ and Lents CA 2008. Energy metabolism and leptin: effects on neuroendocrine regulation of reproduction in the gilt and sow. Reproduction in Domestic Animals 43, 324-330.

Barb CR, Hausman GJ, Rekaya R, Lents CA, Lkhagvadorj S, Qu L, Cai W, Couture OP, Anderson LL, Dekkers JC and Tuggle CK 2010b. Gene expression in hypothalamus, liver and adipose tissues and food intake response to melanocortin- 4 receptor (MC4R) agonist in pigs expressing MC4R mutations. Physiological Genomics 41, 254-268.

Barb CR, Kraeling RR, Rampacek GB and Estienne MJ 2000. Current concepts of the onset of puberty in the gilt. Reproduction in Domestic Animals 35, 82-88.

Barb CR, Kraeling RR, Rampacek GB and Hausman GJ 2006. The role of neuropeptide $Y$ and interaction with leptin in regulating feed intake and luteinizing hormone and growth hormone secretion in the pig. Reproduction 131, 1127-1135.

Barb CR, Robertson AS, Barrett JB, Kraeling RR and Houseknecht KL 2004b. The role of melanocortin-3 and -4 receptor in regulating appetite, energy homeostasis and neuroendocrine function in the pig. Journal of Endocrinology 181, 39-52. Basini G, Grasselli F, Bussolati S, Ciccimarra R, Maranesi M, Bufalari A, Parillo F and Zerani M 2018. Presence and function of kisspeptin/KISS1R system in swine ovarian follicles. Theriogenology $115,1-8$. 
Bedenbaugh MN, D'Oliveira M, Cardoso RC, Hileman SM, Williams GL and Amstalden M 2017. Pubertal Escape from estradiol negative feedback in ewe lambs is not accounted for by decreased ESR1 mRNA or protein in kisspeptin neurons. Endocrinology 159, 426-438.

Beltramo M and Decourt C 2018. Towards new strategies to manage livestock reproduction using kisspeptin analogs. Theriogenology 112, 2-10.

Beltramo M, Robert V, Galibert M, Madinier JB, Marceau P, Dardente H, Decourt C, De Roux N , Lomet D , Delmas AF, Caraty AF and Aucagne V 2015. Rational design of triazololipopeptides analogs of kisspeptin inducing a long-lasting increase of gonadotropins. Journal of Medicinal Chemistry 58, 3459-3470.

Beltranena E, Aherne FX, Foxcroft GR and Kirkwood RN 1991. Effects of pre- and postpubertal feeding on production traits at first and second estrus in gilts. Journal of Animal Science 69, 886-893.

Berardinelli JG, Ford JJ, Christenson RK and Anderson LL 1984. Luteinizing hormone secretion in ovariectomized gilts: effects of age, reproductive state and estrogen replacement. Journal of Animal Science 58, 165-173.

Bertoldo MJ, Holyoake PK, Evans G and Grupen CG 2012. Seasonal variation in the ovarian function of sows. Reproduction, Fertility and Development 24, 822-834.

Bloemhof S, Mathur PK, Knol EF and van der Waaij EH 2013. Effect of daily environmental temperature on farrowing rate and total born in dam line sows. Journal of Animal Science 91, 2667-2679.

Booth PJ, Cosgrove JR and Foxcroft GR 1996. Endocrine and metabolic responses to realimentation in feed-restricted prepubertal gilts: associations among gonadotropins, metabolic hormones, glucose, and uteroovarian development Journal of Animal Science 74, 840-848.

Britt JH, Esbenshade KL and Heller K 1986. Responses of seasonally anestrous gilts and weaned primiparous sows to treatment with pregnant mare's serum gonadotropin and Altrenogest. Theriogenology 26, 697-707.

Calderón Díaz JA, Vallet JL, Boyd RD, Lents CA, Prince TJ, DeDecker AE, Phillips CE, Foxcroft $G$ and Stalder KJ 2017. Effect of feeding three lysine to energy diets on growth, body composition and age at puberty in replacement gilts. Animal Reproduction Science 184, 1-10.

Camous S, Prunier A and Pelletier J 1985. Plasma prolactin, LH, FSH and estrogen excretion patterns in gilts during sexual development. Journal of Animal Science 60, 1308-1317.

Caraty A, Lomet D, Sebert ME, Guillaume D, Beltramo M and Evans NP 2013. Gonadotrophin-releasing hormone release into the hypophyseal portal blood of the ewe mirrors both pulsatile and continuous intravenous infusion of kisspeptin: an insight into kisspeptin's mechanism of action. Journal of Neuroendocrinology 25, 537-546.

Caraty A, Smith JT, Lomet D, Ben Said S, Morrissey A, Cognie J, Doughton B, Baril $G$, Briant C and Clarke IJ 2007a. Kisspeptin synchronizes preovulatory surges in cyclical ewes and causes ovulation in seasonally acyclic ewes. Endocrinology 148, 5258-5267.

Caraty A, Smith JT, Lomet D, Said SB, Morrissey A, Cognie J, Doughton B, Baril G, Briant C and Clarke IJ 2007b. Kisspeptin synchronizes preovulatory surges in cyclical ewes and causes ovulation in seasonally acyclic ewes. Endocrinology 148, 5258-5267.

Cardoso RC, Alves BR, Sharpton SM, Williams GL and Amstalden M 2015. Nutritional programming of accelerated puberty in heifers: involvement of pro-opiomelanocortin neurones in the arcuate nucleus. Journal of Neuroendocrinology 27, 647-657.

Cox NM, Esbenshade KL and Britt JH 1983. Treatment of long-term anestrous sows with estradiol benzoate and $\mathrm{GnRH}$ : response of serum $\mathrm{LH}$ and occurrence of estrus. Theriogenology 20, 499-507.

Cox NM, Ramirez JL, Matamoros IA, Bennett WA and Britt JH 1987. Influence of season on estrous and luteinizing hormone responses to estradiol benzoate in ovariectomized sows. Theriogenology 27, 395-405.

Czaja K, Lakomy M, Kaleczyc J, Barb CR, Rampacek GB and Kraeling RR 2002a. Leptin receptors, NPY, and tyrosine hydroxylase in autonomic neurons supplying fat depots in a pig. Biochemical and Biophysical Research Communications 293, 1138-1144.

Czaja K, Lakomy M, Sienkiewicz W, Kaleczyc J, Pidsudko Z, Barb CR, Rampacek $\mathrm{GB}$ and Kraeling RR 2002b. Distribution of neurons containing leptin receptors in the hypothalamus of the pig. Biochemical and Biophysical Research Communications 298, 333-337.

d'Anglemont de Tassigny X, Fagg LA, Dixon JP, Day K, Leitch HG, Hendrick AG, Zahn D, Franceschini I, Caraty A, Carlton MB, Aparicio SA and Colledge WH
2007. Hypogonadotropic hypogonadism in mice lacking a functional Kiss1 gene Proceedings of the National Academy of Sciences 104, 10714-10719.

De Guillebon A, Dwyer A, Wahab F, Cerrato F, Wu I-H, Hall JE, Martin KA, Plummer L, Au M, Pitteloud N, Lapatto R, Broder-Fingert S, Paraschos S, Hughes V, Seminara SB, Chan Y-M, Van der Kamp HJ, Nader S, Min L, Bianco SDC, Kaiser UB, Kirsch $S$, Quinton $R$, Cheetham $T$, Ozata $M$, Ten $S$ Chanoine J-P and Schiffmann R 2011. GnRH-deficient phenotypes in humans and mice with heterozygous variants in KISS1/Kiss1. The Journal of Clinical Endocrinology \& Metabolism 96, E1771-E1781.

De Rensis F, Ziecik AJ and Kirkwood RN 2017. Seasonal infertility in gilts and sows: aetiology, clinical implications and treatments. Theriogenology 96, 111-117.

de Roux N, Genin E, Carel JC, Matsuda F, Chaussain JL and Milgrom E 2003. Hypogonadotropic hypogonadism due to loss of function of the KiSS1-derived peptide receptor GPR54. Proceedings of the National Academy of Sciences 100, 10972-10976.

Decourt C, Caraty A, Briant C, Guillaume D, Lomet D, Chesneau D, Lardic L, Duchamp G, Reigner F, Monget P, Dufourny L, Beltramo M and Dardente $H$ 2014. Acute injection and chronic perfusion of kisspeptin elicit gonadotropins release but fail to trigger ovulation in the mare. Biology of Reproduction 90, 36. Decourt C, Robert V, Anger K, Galibert M, Madinier JB, Liu X, Dardente H, Lomet $D$, Delmas AF, Caraty A, Herbison AE, Anderson GM, Aucagne V and Beltramo M 2016. A synthetic kisspeptin analog that triggers ovulation and advances puberty. Scientific Reports 6, 26908.

Diekman MA, Trout WE and Anderson LL 1983. Serum profiles of LH, FSH and prolactin from 10 weeks of age until puberty in gilts. Journal of Animal Science 56, 139-145.

Edwards S and Foxcroft GR 1983. Endocrine changes in sows weaned at two stages of lactation. Journal of Reproduction and Fertility 67, 161-172.

Endo N, Tamesaki C, Ohkura S, Wakabayashi Y, Matsui H, Tanaka A, Watanabe T, Okamura $\mathrm{H}$ and Tanaka T 2015. Differential changes in luteinizing hormone secretion after administration of the investigational metastin/kisspeptin analog TAK-683 in goats. Animal Reproduction Science 159, 87-93.

Ezzat Ahmed A, Saito H, Sawada T, Yaegashi T, Yamashita T, Hirata TI, Sawai K and Hashizume T 2009. Characteristics of the stimulatory effect of kisspeptin-10 on the secretion of luteinizing hormone, follicle-stimulating hormone and growth hormone in prepubertal male and female cattle. Journal of Reproduction and Development 55, 650-654.

Franceschini I, Lomet D, Cateau M, Delsol G, Tillet $Y$ and Caraty A 2006. Kisspeptin immunoreactive cells of the ovine preoptic area and arcuate nucleus co-express estrogen receptor alpha. Neuroscience Letters 401, 225-230.

Funes S, Hedrick JA, Vassileva G, Markowitz L, Abbondanzo S, Golovko A, Yang S, Monsma FJ and Gustafson EL 2003. The KiSS-1 receptor GPR54 is essential for the development of the murine reproductive system. Biochemical and Biophysical Research Communications 312, 1357-1363.

Goodman RL, Hileman SM, Nestor CC, Porter KL, Connors JM, Hardy SL, Millar RP, Cernea M, Coolen LM and Lehman MN 2013. Kisspeptin, neurokinin B, and dynorphin act in the arcuate nucleus to control activity of the GnRH pulse generator in ewes. Endocrinology 154, 4259-4269.

Goto Y, Endo N, Nagai K, Ohkura S, Wakabayashi Y, Tanaka A, Matsui H, Kusaka M, Okamura $\mathrm{H}$ and Tanaka T 2014. Ovarian and hormonal responses to follicular phase administration of investigational metastin/kisspeptin analog, TAK-683, in goats. Reproduction in Domestic Animals 49, 338-342.

Hashizume T, Saito H, Sawada T, Yaegashi T, Ezzat AA, Sawai K and Yamashita T 2010. Characteristics of stimulation of gonadotropin secretion by kisspeptin-10 in female goats. Animal Reproduction Science 118, 37-41.

Hausman GJ, Barb CR and Lents CA 2012. Leptin and reproductive function. Biochimie 94, 2075-2081.

leda N, Uenoyama Y, Tajima Y, Nakata T, Kano M, Naniwa Y, Watanabe Y, Minabe S, Tomikawa J, Inoue N, Matsuda F, Ohkura S, Maeda K and Tsukamura H 2014. KISS1 gene expression in the developing brain of female pigs in pre- and peripubertal periods. Journal of Reproduction and Development 60, 312-316.

Kadokawa H, Matsui M, Hayashi K, Matsunaga N, Kawashima C, Shimizu T and Miyamoto A 2008. Peripheral administration of kisspeptin-10 increases plasma concentrations of GH as well as $\mathrm{LH}$ in prepubertal holstein heifers. Journal of Endocrinology 196, 331-334.

Kanai N, Endo N, Ohkura S, Wakabayashi Y, Matsui H, Matsumoto H, Ishikawa K, Tanaka A, Watanabe T, Okamura H and Tanaka T 2017. An administration of 
TAK-683 at a minimally effective dose for luteinizing hormone stimulation under the absence of the ovary induces luteinizing hormone surge in ovary-intact goats. Journal of Reproduction and Development 63, 305-310.

Kesner JS, Price-Taras EA, Kraeling RR, Rampacek GB and Barb CR 1989. Negative feedback as an obligatory antecedent to the estradiol-induced luteinizing hormone surge in ovariectomized pigs. Biology of Reproduction 41, 409-413.

Kineman RD, Kraeling RR, Crim JW, Leshin LS, Barb CR and Rampacek GB 1989. Localization of proopiomelanocortin (POMC) immunoreactive neurons in the forebrain of the pig. Biology of Reproduction 40, 1119-1126.

Kineman RD, Leshin LS, Crim JW, Rampacek GB and Kraeling RR 1988. Localization of luteinizing hormone-releasing hormone in the forebrain of the pig. Biology of Reproduction 39, 665-672.

Knauer MT, Stalder KJ, Karriker L, Johnson C and Layman L 2006. Factors influencing sow culling. In Symposium review presented at the National Swine Improvement Federation Conference Annual Meeting, 7-8 December 2006 Nashville, TN.

Kotani M, Detheux M, Vandenbogaerde A, Communi D, Vanderwinden JM, Le Poul E, Brezillon S, Tyldesley R, Suarez-Huerta N, Vandeput F, Blanpain C Schiffmann SN, Vassart $G$ and Parmentier M 2001. The metastasis suppressor gene KiSS-1 encodes kisspeptins, the natural ligands of the orphan $\mathrm{G}$ proteincoupled receptor GPR54. Journal of Biological Chemistry 276, 34631-34636.

Kraeling RR and Barb CR 1990. Hypothalamic control of gonadotrophin and prolactin secretion in pigs. Journal of Reproduction and Fertility Supplement 40, 3-17.

Kraeling RR, Johnson B, Barb CR and Rampacek GB 1998. Evidence for a luteinizing hormone surge center in the hypothalamus of the pig. Biology of Reproduction 58, 1199-1205.

Kuehn LA, Nonneman DJ, Klindt JM and Wise TH 2009. Genetic relationships of body composition, serum leptin, and age at puberty in gilts. Journal of Animal Science 87, 477-483.

Laoharatchatathanin T, Terashima R, Yonezawa T, Kurusu S and Kawaminami M 2015. Augmentation of metastin/kisspeptin mRNA expression by the proestrous luteinizing hormone surge in granulosa cells of rats: implications for luteinization. Biology of Reproduction 93, 15.

Lapatto R, Pallais JC, Zhang D, Chan YM, Mahan A, Cerrato F, Le WW, Hoffman GE and Seminara SB 2007. Kiss1 -/- mice exhibit more variable hypogonadism than Gpr54 -/- mice. Endocrinology 148, 4927-4936.

Lents CA, Heidorn NL, Barb CR and Ford JJ 2008. Central and peripheral administration of kisspeptin activates gonadotropin but not somatotropin secretion in prepubertal gilts. Reproduction 135, 879-887.

Leshin LS, Rund LA, Crim JW and Kiser TE 1988. Immunocytochemical localization of luteinizing hormone-releasing hormone and proopiomelanocortin neurons within the preoptic area and hypothalamus of the bovine brain. Biology of Reproduction 39, 963-975.

Li S, Ren J, Yang G, Guo Y and Huang L 2008. Characterization of the porcine kisspeptins receptor gene and evaluation as candidate for timing of puberty in sows. Journal of Animal Breeding and Genetics 125, 219-227.

Lin J, Barb CR, Kraeling RR and Rampacek GB 2001. Developmental changes in the long form leptin receptor and related neuropeptide gene expression in the pig brain. Biology of Reproduction 64, 1614-1618.

Lin J, Barb CR, Matteri RL, Kraeling RR, Chen X, Meinersmann RJ and Rampacek GB 2000. Long form leptin receptor mRNA expression in the brain, pituitary, and other tissues in the pig. Domestic Animal Endocrinology 19, 53-61.

Louis GW, Greenwald-Yarnell M, Phillips R, Coolen LM, Lehman MN and Myers JMG 2011. Molecular mapping of the neural pathways linking leptin to the neuroendocrine reproductive axis. Endocrinology 152, 2302-2310.

Love RJ, Evans G and Klupiec C 1993. Seasonal effects on fertility in gilts and sows. Journal of Reproduction and Fertility Supplement 48, 191-206.

Lutz JB, Rampacek GB and Kraeling RR 1985. Induction of ovulation in the prepubertal gilt by pulsatile administration of gonadotropin releasing hormone. Domestic Animal Endocrinology 2, 61-65.

Lutz JB, Rampacek GB, Kraeling RR and Pinkert CA 1984. Serum luteinizing hormone and estrogen profiles before puberty in the gilt. Journal of Animal Science $58,686-691$.

Magee C, Foradori CD, Bruemmer JE, Arreguin-Arevalo JA, McCue PM, Handa RJ, Squires EL and Clay CM 2009. Biological and anatomical evidence for kisspeptin regulation of the hypothalamic-pituitary-gonadal axis of estrous horse mares. Endocrinology 150, 2813-2821.
Matsui H, Takatsu Y, Kumano S, Matsumoto H and Ohtaki T 2004. Peripheral administration of metastin induces marked gonadotropin release and ovulation in the rat. Biochemical and Biophysical Research Communications 320, 383-388.

Mauget R 1982. Seasonality of reproduction in the wild boar. In Control of pig reproduction (ed. DJA Cole and GR Foxcroft), pp. 509-526. Butterworth Scientific, London, UK.

Mayer C, Acosta-Martinez M, Dubois SL, Wolfe A, Radovick S, Boehm U and Levine JE 2010. Timing and completion of puberty in female mice depend on estrogen receptor $\alpha$-signaling in kisspeptin neurons. Proceedings of the National Academy of Sciences 107, 22693-22698.

Messager S, Chatzidaki EE, Ma D, Hendrick AG, Zahn D, Dixon J, Thresher RR, Malinge I, Lomet D, Carlton MB, Colledge WH, Caraty A and Aparicio SA 2005 Kisspeptin directly stimulates gonadotropin-releasing hormone release via $G$ protein-coupled receptor 54. Proceedings of the National Academy of Sciences 102, 1761-1766.

Miller PS, Moreno R and Johnson RK 2011. Effects of restricting energy during the gilt developmental period on growth and reproduction of lines differing in lean growth rate: responses in feed intake, growth, and age at puberty. Journal of Animal Science 89, 342-354.

Navarro VM, Castellano JM, Fernandez-Fernandez R, Barreiro ML, Roa J, SanchezCriado JE, Aguilar E, Dieguez C, Pinilla L and Tena-Sempere M 2004. Developmental and hormonally regulated messenger ribonucleic acid expression of KiSS-1 and its putative receptor, GPR54, in rat hypothalamus and potent luteinizing hormone-releasing activity of KiSS-1 peptide. Endocrinology 145, 4565-4574. Nestor CC, Briscoe AM, Davis SM, Valent M, Goodman RL and Hileman SM 2012 Evidence of a role for kisspeptin in puberty onset in sheep. Endocrinology 153 , 2756-2765.

Nonneman D, Lents C, Rohrer G, Rempel L and Vallet J 2014. Genome-wide association with delayed puberty in swine. Animal Genetics 45, 130-132.

Nonneman DJ, Schneider JF, Lents CA, Wiedmann RT, Vallet JL and Rohrer GA 2016. Genome-wide association and identification of candidate genes for age at puberty in swine. BMC Genetics 17, 1-9.

Ohtaki T, Shintani $Y$, Honda S, Matsumoto $H$, Hori A, Kanehashi $K$, Terao $Y$, Kumano S, Takatsu Y, Masuda Y, Ishibashi Y, Watanabe T, Asada M Yamada T, Suenaga M, Kitada C, Usuki S, Kurokawa T, Onda H, Nishimura $O$ and Fujino M 2001. Metastasis suppressor gene KiSS-1 encodes peptide ligand of a G-protein-coupled receptor. Nature 411, 613-617.

Parker PA, Coffman EA, Pohler KG, Daniel JA, Aucagne V, Beltramo M and Whitlock BK 2019. Acute and subacute effects of a synthetic kisspeptin analog, $\mathrm{C6}$, on serum concentrations of luteinizing hormone, follicle stimulating hormone, and testosterone in prepubertal bull calves. Theriogenology 130, 111-119.

Peltoniemi OA and Virolainen JV 2006. Seasonality of reproduction in gilts and sows. Society of Reproduction and Fertilility Supplement 62, 205-218.

Peng J, Tang M, Zhang BP, Zhang P, Zhong T, Zong T, Yang B and Kuang HB 2013. Kisspeptin stimulates progesterone secretion via the Erk1/2 mitogenactivated protein kinase signaling pathway in rat luteal cells. Fertility and Sterility 99, 1436-1443.

Pompolo S, Pereira A, Estrada KM and Clarke IJ 2006. Colocalization of kisspeptin and gonadotropin-releasing hormone in the ovine brain. Endocrinology 147, 804-810.

Prunier A, Martin C, Mounier AM and Bonneau M 1993. Metabolic and endocrine changes associated with undernutrition in the peripubertal gilt. Journal of Animal Science 71, 1887-1894.

Qian H, Barb CR, Compton MM, Hausman GJ, Azain MJ, Kraeling RR and Baile CA 1999. Leptin mRNA expression and serum leptin concentrations as influenced by age, weight, and estradiol in pigs. Domestic Animal Endocrinology 16, 135-143. Qiu J, Fang Y, Bosch MA, Rønnekleiv OK and Kelly MJ 2011. Guinea pig kisspeptin neurons are depolarized by leptin via activation of TRPC channels. Endocrinology 152, 1503-1514.

Quennell JH, Howell CS, Roa J, Augustine RA, Grattan DR and Anderson GM 2011. Leptin deficiency and diet-induced obesity reduce hypothalamic kisspeptin expression in mice. Endocrinology 152, 1541-1550.

Quennell JH, Mulligan AC, Tups A, Liu X, Phipps SJ, Kemp CJ, Herbison AE, Grattan DR and Anderson GM 2009. Leptin indirectly regulates gonadotropin-releasing hormone neuronal function. Endocrinology 150, 2805-2812.

Rahayu LP, Behiry ME, Endo N and Tanaka T 2017. Effect of investigational kisspeptin/metastin analog, TAK-683, on luteinizing hormone secretion at different stages of the luteal phase in goats. Journal of Reproduction and Development 63, 221-226. 
Ralph C, Kirkwood R, Beltramo M, Aucagne V and Tilbrook A 2018. A single injectin of compound 6 evoked an LH surge and ovultion in 18 week old gilts. In Proceedings of the Annual Meeting of the Endocrine Society, 17-20 March 2018, Chicago, IL, p. 8.

Ralph CR, Kirkwood RN and Tilbrook AJ 2017. A single intravenous injection of kisspeptin evokes an increase in luteinising hormone in 15- and 18-wekk old gilts. Animal Production Science 57, 2469.

Redmond JS, Baez-Sandoval GM, Spell KM, Spencer TE, Lents CA, Williams GL and Amstalden M 2011 a. Developmental changes in hypothalamic Kiss1 expression during activation of the pulsatile release of luteinising hormone in maturing ewe lambs. Journal of Neuroendocrinology 23, 815-822.

Redmond JS, Macedo GG, Velez IC, Caraty A, Williams GL and Amstalden M $2011 \mathrm{~b}$. Kisspeptin activates the hypothalamic-adenohypophyseal-gonadal axis in prepubertal ewe lambs. Reproduction 141, 541-548.

Saadeldin IM, Swelum AA, Abdelazim AM and Almadaly EA 2018. Effect of kisspeptin on the developmental competence and early transcript expression in porcine oocytes parthenogenetically activated with different methods. Biomedical Research International 2018, 3693602.

Saito $H$, Sasaki $Y$ and Koketsu $Y$ 2011. Associations between age of gilts at first mating and lifetime performance or culling risk in commercial herds. Journal of Veterinary Medical Science 73, 555-559.

Sebert ME, Lomet D, Said SB, Monget P, Briant C, Scaramuzzi RJ and Caraty A 2010. Insights into the mechanism by which kisspeptin stimulates a preovulatory LH surge and ovulation in seasonally acyclic ewes: potential role of estradiol. Domestic Animal Endocrinology 38, 289-298.

Seminara SB, Messager S, Chatzidaki EE, Thresher RR, Acierno JSJ, Shagoury JK, Bo-Abbas Y, Kuohung W, Schwinof KM, Hendrick AG, Zahn D, Dixon J, Kaiser UB, Slaugenhaupt SA, Gusella JF, O'Rahilly S, Carlton MB, Crowley WFJ, Aparicio SA and Colledge WH 2003. The GPR54 gene as a regulator of puberty. New England Journal of Medicine 349, 1614-1627.

Semple RK, Achermann JC, Ellery J, Farooqi IS, Karet FE, Stanhope RG, O'Rahilly S and Aparicio SA 2005. Two novel missense mutations in G protein-coupled receptor 54 in a patient with hypogonadotropic hypogonadism. Journal of Clinical Endocrinololgy and Metabolism 90, 1849-1855.

Sevillano CA, Mulder HA, Rashidi H, Mathur PK and Knol EF 2016. Genetic variation for farrowing rate in pigs in response to change in photoperiod and ambient temperature. Journal of Animal Science 94, 3185-3197.

Shahab M, Mastronardi C, Seminara SB, Crowley WF, Ojeda SR and Plant TM 2005. Increased hypothalamic GPR54 signaling: a potential mechanism for initiation of puberty in primates. Proceedings of the National Academy of Sciences 102, 2129-2134.

Smith CA, Almond GW and Dial GD 1991. Effects of season and estradiol-17 $\beta$ on luteinizing hormone release in ovariectomized sows. Journal of Animal Science 69, 4907-4913.

Smith JT, Clay CM, Caraty A and Clarke IJ 2007. KiSS-1 messenger ribonucleic acid expression in the hypothalamus of the ewe is regulated by sex steroids and season. Endocrinology 148, 1150-1157.

Smith JT, Coolen LM, Kriegsfeld LJ, Sari IP, Jaafarzadehshirazi MR, Maltby M, Bateman K, Goodman RL, Tilbrook AJ, Ubuka T, Bentley GE, Clarke IJ and Lehman MN 2008a. Variation in kisspeptin and gonadotropin-inhibitory hormone expression and terminal connections to $\mathrm{GnRH}$ neurons in the brain: a nove medium for seasonal breeding in the sheep. Endocrinology 149, 5770-5782.

Smith JT, Dungan HM, Stoll EA, Gottsch ML, Braun RE, Eacker SM, Clifton DK and Steiner RA 2005. Differential regulation of KiSS-1 mRNA expression by sex steroids in the brain of the male mouse. Endocrinology 146, 2976-2984.

Smith JT, Li Q, Yap KS, Shahab M, Roseweir AK, Millar RP and Clarke IJ 2011 Kisspeptin is essential for the full preovulatory $\mathrm{LH}$ surge and stimulates $\mathrm{GnRH}$ release from the isolated ovine median eminence. Endocrinology 152, 1001-1012.

Smith JT, Rao A, Pereira A, Caraty A, Millar RP and Clarke IJ 2008b. Kisspeptin is present in ovine hypophysial portal blood but does not increase during the preovulatory luteinizing hormone surge: evidence that gonadotropes are not direct targets of kisspeptin in vivo. Endocrinology 149, 1951-1959.

Sonstegard TS, Carlson D, Lancto C and Fahrenkrug SC 2016. Precision animal breeding as a sustainable, non-GMO solution for improving animal production and welfare. Biennial Conference of the Australian Society of Animal Production 31, 316-317.

Sonstegard TS, Fahrenkrug SC and Carlson D 2017. Precision animal breeding to make genetically castrated animals for improved animal welfare and alternative breeding applications. Journal of Animal Science 95, 149.
Stancic I, Stancic B, Bozic A, Anderson R, Harvey R and Gvozdic D 2011. Ovarian activity and uterus organometry in delayed puberty gilts. Theriogenology 76 , 1022-1026.

Suzuki S, Kadokawa H and Hashizume T 2008. Direct kisspeptin-10 stimulation on luteinizing hormone secretion from bovine and porcine anterior pituitary cells. Animal Reproduction Science 103, 360-365.

Tanaka T, Ohkura S, Wakabayashi Y, Kuroiwa T, Nagai K, Endo N, Tanaka A, Matsui H, Kusaka M and Okamura H 2013. Differential effects of continuous exposure to the investigational metastin/kisspeptin analog TAK-683 on pulsatile and surge mode secretion of luteinizing hormone in ovariectomized goats. Journal of Reproduction and Development 59, 563-568.

Tantasuparuk W, Lundeheim N, Dalin AM, Kunavongkrit A and Einarsson S 2000. Reproductive performance of purebred Landrace and Yorkshire sows in Thailand with special reference to seasonal influence and parity number. Theriogenology 54, 481-496.

Tart JK, Johnson RK, Bundy JW, Ferdinand NN, McKnite AM, Wood JR, Miller PS, Rothschild MF, Spangler ML, Garrick DJ, Kachman SD and Ciobanu DC 2013. Genome-wide prediction of age at puberty and reproductive longevity in sows. Animal Genetics 44, 387-397.

Thompson EL, Patterson M, Murphy KG, Smith KL, Dhillo WS, Todd JF, Ghatei MA and Bloom SR 2004. Central and peripheral administration of kisspeptin-10 stimulates the hypothalamic-pituitary-gonadal axis. Journal of Neuroendocrinology 16, 850-858.

Thorson JF, Heidorn NL, Ryu V, Czaja K, Nonneman DJ, Barb CR, Hausman GJ, Rohrer GA, Prezotto LD, McCosh RB, Wright EC, White BR, Freking BA, Oliver WT, Hileman SM and Lents CA 2017. Relationship of neuropeptide FF receptors with pubertal maturation of gilts. Biology of Reproduction 96, 617-634.

Thorson JF, Prezotto LD, Adams H, Petersen SL, Clapper JA, Wright EC, Oliver WT, Freking BA, Foote AP, Berry ED, Nonneman DJ and Lents CA 2018. Energy balance affects pulsatile secretion of luteinizing hormone from the adenohypophesis and expression of neurokinin B in the hypothalamus of ovariectomized gilts. Biology of Reproduction 99, 433-445.

Tomikawa J, Homma T, Tajima S, Shibata T, Inamoto $\mathrm{Y}$, Takase $\mathrm{K}$, Inoue $\mathrm{N}$, Ohkura S, Uenoyama Y, Maeda KI and Tsukamura H 2010. Molecular characterization and estrogen regulation of hypothalamic KISS1 gene in the pig. Biology of Reproduction 82, 313-319.

Tummaruk P, Kesdangsakonwut $S$ and Kunavongkrit A 2009. Relationships among specific reasons for culling, reproductive data, and gross morphology of the genital tracts in gilts culled due to reproductive failure in Thailand. Theriogenology 71, 369-375.

Tummaruk P, Tantasuparuk W, Techakumphu M and Kunavongkrit A 2007. Age, body weight and backfat thickness at first observed oestrus in crossbred Landrace $\mathrm{x}$ Yorkshire gilts, seasonal variations and their influence on subsequence reproductive performance. Animal Reproduction Science 99 167-181.

Whisnant CS and Harrell RJ 2002. Effect of short-term feed restriction and refeeding on serum concentrations of leptin, luteinizing hormone and insulin in ovariectomized gilts. Domestic Animal Endocrinology 22, 73-80.

Whitlock BK, Daniel JA, Amelse LL, Tanco VM, Chameroy KA and Schrick FN 2015. Kisspeptin receptor agonist (FTM080) increased plasma concentrations of luteinizing hormone in anestrous ewes. PeerJournal 3, e1382.

Whitlock BK, Daniel JA, Wilborn RR, Rodning SP, Maxwell HS, Steele BP and Sartin JL 2008. Interaction of estrogen and progesterone on kisspeptin-10-stimulated luteinizing hormone and growth hormone in ovariectomized cows. Neuroendocrinology 88, 212-215.

Yamamura T, Wakabayashi Y, Sakamoto K, Matsui H, Kusaka M, Tanaka T, Ohkura $S$ and Okamura $H$ 2014. The effects of chronic subcutaneous administration of an investigational kisspeptin analog, TAK-683, on gonadotropinreleasing hormone pulse generator activity in goats. Neuroendocrinology $100,250-264$

Zhou D, Zhuo Y, Che L, Lin Y, Fang Z and Wu D 2014. Nutrient restriction induces failure of reproductive function and molecular changes in hypothalamuspituitary-gonadal axis in postpubertal gilts. Molecular Biology Reports 41 , 4733-4742.

Zhuo Y, Zhou D, Che L, Fang Z, Lin Y and Wu D 2014. Feeding prepubescent gilts a high-fat diet induces molecular changes in the hypothalamuspituitary-gonadal axis and predicts early timing of puberty. Nutrition 30 , 890-896. 